\title{
ЧИННИКИ УТВОРЕННЯ МУЛЬД ОСІДАННЯ ЗЕМНОЇ ПОВЕРХНІ У РАЙОНАХ ПІДЗЕМНИХ ГІРНИЧИХ ВИРОБОК
}

У статті представлено результати геологічних та геодезичних досліджень шахтних полів рудника «Калуш» Калуш-Голинського родовища. Наведено результати розрахунків максимальної глибини мульди осідання залежно від коефіцієнта запасу міциності ичіликів та припливу рідини у шахти. Здійснено аналіз впливу заповнення шахт насиченими соляними розсолами на руйнування ціликів. Величини фактичних осідань земної поверхні шахтних полів рудника «Калуш», визначені методом високоточного геометричного нівелювання, на сьогодні не перевищують максимальних величин, отриманих на основі геолого-механічних розрахунків.

Ключові слова: деформація земної поверхні; гірничі виробки; оцінка глибини мульди зрушень.

Рис.: 1. Табл.: 2. Бібл.: 14.

Актуальність теми дослідження. Упродовж останніх десятиліть розвиток господарського комплексу України відбувається за умов постійного нарощування техногенної дестабілізації геологічного середовища. Як наслідок, спостерігаємо подальше збільшення кількості кризових явищ в екологічних системах, зокрема активізацію небезпечних екзогенних геологічних процесів (ЕГП) практично на всій території країни. Залучення територій із розвитком природних ЕГП у сферу господарської діяльності призводить до змін навколишнього середовища, які супроводжуються техногенним посиленням природних ЕГП: порушення рівноваги породних масивів при видобутку корисних копалин, забудова схилів, вирубка лісів тощо. Усе це спричинило зародження нових явищ, які раніше не спостерігались у природі - осідання земної поверхні над гірничими виробками, техногенне підтоплення значних територій під впливом гідротехнічного будівництва чи збільшення площ зрошувальних земель. Розвиток та активізація зсувного процесу викликає руйнування та деформації багатьох промислових, інженерних, житлових та громадських споруд. Недостатній за останні роки рівень фінансування робіт з моніторингу ЕГП став основною причиною значного зменшення обсягів польових робіт, скорочення кількості стаціонарів та спостережень на них i, як наслідок, низький рівень достовірності наявної інформації.

Постановка проблеми. Вплив на довкілля підземних способів видобування корисних копалин різноплановий: це і вплив на літосферу, забруднення гідросфери та атмосфери. У процесі видобування корисних копалин порушується структура порід, що сприяє інтенсивному вивітрюванню, розвитку тріщинуватості, порушенню гравітаційної рівноваги, зміні гідрогеологічних умов. Кар'єри змінюють природні фізичні поля та ландшафти місцевості, утворюючи антропогенні ландшафти. Під час підземного видобування корисних копалин відбувається осідання поверхні землі, що становить загрозу для об'єктів, розташованих у зоні мульди осідання, і навіть людському життю. Причиною виникнення провалів земної поверхні на території рудників $є$ підземні обвали, які виникли внаслідок підтоплення грунтовими водами підземних гірничих полів рудників. Своєчасне реагування на виникнення подібних техногенних руйнувань земної поверхні потребує періодичного ведення їхнього моніторингу, а саме визначення деформацій та осідань [1]. Під моніторингом, зазвичай, розуміють спостереження за навколишнім середовищем, що становить динамічну систему, тобто систему, яка постійно змінюється, 3 метою її контролю, вивчення і прогнозу.

Аналіз останніх досліджень і публікацій. Визначення показників деформації на ділянці під впливом відкритого кар'єру вимагає застосування високоточних геодезичних методів і засобів вимірювань [2], щоб забезпечити швидке реагування на небезпеку. Численні дослідження проведено науковцями з метою встановлення небезпек для будівель та споруд, спричинених видобуванням корисних копалин.

() Гера О. В., Гринішак М. Я., Дорош Л. І., 2021 
3 урахуванням різноманітності та невизначеності факторів, що викликають пошкодження будівлі, А. Малиновська запропонувала метод нечіткої аргументації для оцінки величини шкідливого впливу гірничих робіт на будівлі [3].

У попередніх дослідженнях А. Малиновської та Р. Хеймановської використано методи аналізу ГІС для оцінки руйнівного впливу підземного видобутку на будівлі в Польщі та Росії [4].

У роботах [5; 6] представлені принципи точного визначення тривимірних переміщень з використанням технології GNSS. Результати досліджень показують, що в кожній складовій фактичних координат контрольованих точок можна досягнути точності 2-3 мм, а величин зсувів - 3-4 мм. Що стосується великих об'єктів, то технологія GNSS має перевагу, порівняно із класичними дослідженнями, у швидкості виконання спостережень, що проявляється економією фінансових затрат.

У роботі [7] запропоновано методику та інформаційну технологію розрахунку зрушень і деформацій земної поверхні на великих площах, яка базується на сітковій моделі та враховує геологію порід. Приклад використання даної методики розглянутий на територію 11-ти шахт у Донецько-Макіївському регіоні Донбасу із сумарною площею шахтних полів 140,5 км².

Мета статті - визначення геометричних параметрів мульди осідання земної поверхні над шахтними полями для своєчасного оповіщення про небезпеку та запровадження відповідних заходів.

Виклад основного матеріалу. Найбільш яскравою ілюстрацією процесів зрушень i провалів можуть служити калійні рудники Калуш-Голинського родовища калійних солей. Видобуток солі тут здійснювали з незапам'ятних часів до 1912 року шляхом вилуговування з наступним випаровуванням розсолу.

Схема розташування шахтних полів рудника «Калуш» наведена на рис. 1. Рудник складається з чотирьох видобувних полів: Північне сильвінітове, Північне і Центральне каїнітові та Хотинське сильвінітове.

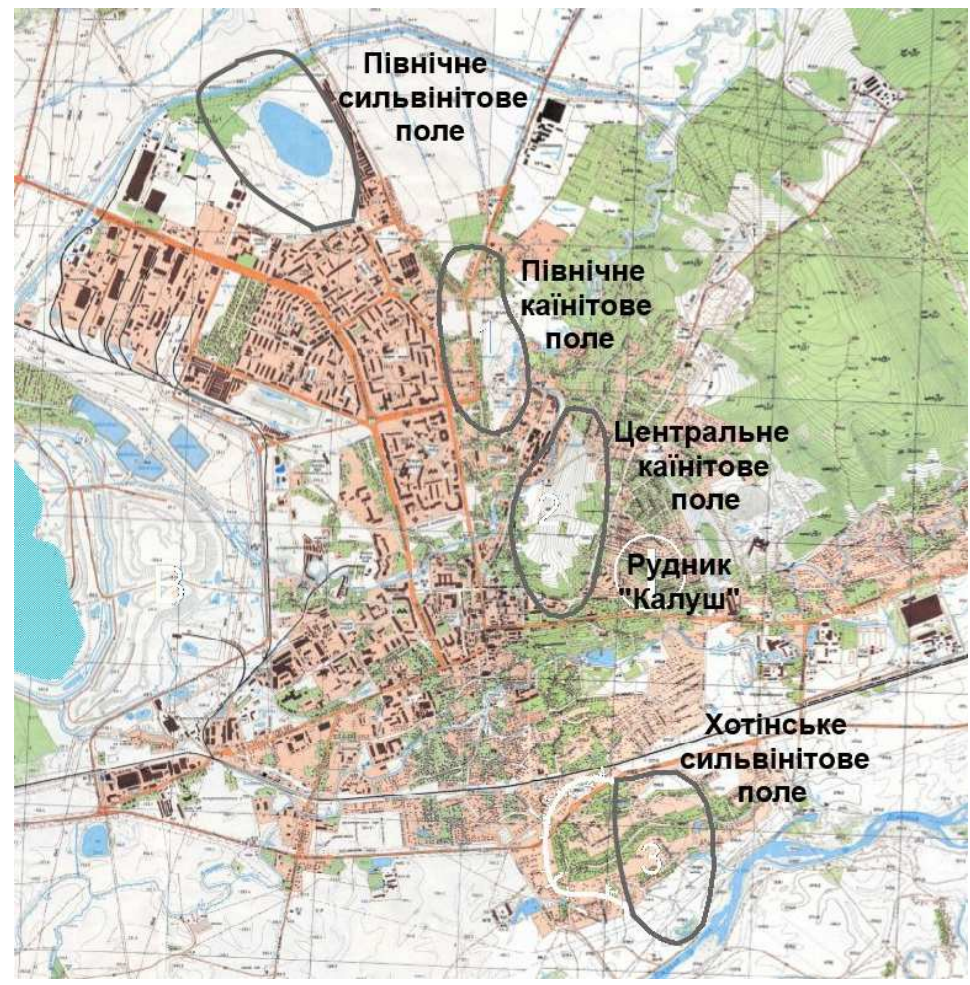

Рис. 1. Оглядова карта Калуш-Голинського родовищча 
На території Північного сильвінітового поля цілики зруйновані, в результаті чого утворилася мульда осідання з озером. Північне і Центральне каїнітові поля заповнені насиченими розсолами, що зменшує навантаження на цілики і підвищує їхню стійкість. Хотинське поле відокремлене від інших двома гідроізоляційними перемичками. Вироблений простір залишається сухим.

У 1970-1980-ті роки над гірничими виробками утворився ряд провалів земної поверхні (найбільший - на Північному каїнітовому полі). Із зони провалу відселено мешканців 40 будинків. На території шахтних полів продовжуються деформації поверхні, що викликає обгрунтовану стурбованість громадськості. Основні закономірності деформацій земної поверхні над соляними шахтами висвітлено у роботах [8; 9].

Для підтримки гірничого масиву в стабільному стані видобуток солей здійснювався камерною системою, залишаючи опорні цілики. Деформації земної поверхні над шахтними полями зумовлені двома причинами: осіданням міжкамерних ціликів під вагою залягаючої вище товщі порід і розвитком соляного карсту.

У гірничій геомеханіці цілики розглядаються як стовпи або стіни необмеженої довжини, які приймають на себе вагу залягаючих вище порід. Стійкість ціликів залежить від міцності солі, яка визначається опором одноосному стисканню $\sigma_{\text {ст. }}$

Міцність цілика визначають за формулою [10]:

$$
\sigma=\sigma_{c m} \times K 1 \times K 2,
$$

де $\sigma_{c m}$ - опір руди одноосному стисканню, т/м², К1 і К2 - коефіцієнти форми.

Запропоновані [11] емпіричні формули для визначення вказаних коефіцієнтів:

$$
K 1=\frac{1}{\left(0,45+0,55 \times \frac{h}{a}\right)}, K 2=1,44 .
$$

У наведених формулах $\mathrm{h}$ - висота, a - ширина цілика за виключенням зони тріщинуватості. Ця формула дає достатньо точні результати при величині відношення $\mathrm{h} / \mathrm{a}$ від 0,3 до 4,0.

Наприклад, при $\mathrm{h} / \mathrm{a}=3$, коефіцієнт $\mathrm{K} 1=0,47, \sigma=0,7 \sigma_{c m}$

Стійкість ціликів визначають коефіцієнтом запасу міцності n, який є відношенням міцності цілика до навантаження:

$$
n=S H \times \frac{\sigma}{S u} \times \gamma \times H,
$$

де $\mathrm{S}_{\mathrm{H}}$ - площа стовпа вищезалягаючих на цілик порід, $\mathrm{Sц} \mathrm{-} \mathrm{площа} \mathrm{цілика,} \gamma$ - об'ємна вага залягаючих вище порід, $\mathrm{H}$ - глибина від поверхні землі до покрівлі виробки.

Для випадку необмеженої послідовності міжкамерних ціликів і камер необмеженої довжини, запас стійкості геомеханічної системи n визначається за формулою:

$$
n=\sigma_{c m}\left(\frac{(a-1)^{3} / h^{\frac{1}{2}}}{\gamma \times H(A+a)+\gamma_{o} \times h_{a}}\right),
$$

де $\sigma_{c т}-$ запас міцності порід цілика на одноосне стискання, 3000 т/ $\mathbf{m}^{2},(\mathrm{a}-1)$ - ширина ціликів за винятком зони впливу вибухових робіт, $\mathrm{m}, \mathrm{h}$ - висота міжкамерного цілика, $\gamma-$

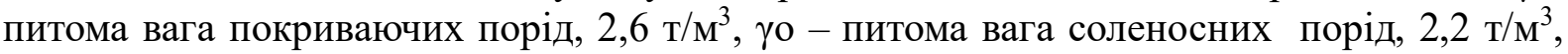
Н - глибина розробки до покрівлі пласта, м, А -ширина камери, м. У розрахункових формулах ширина ціликів зменшена на 1 м, що враховує наявність тріщин, утворених під час проведення вибухів. 
Деформації ціликів залежать від коефіцієнта запасу [10]. При запасі міцності ціликів більше 2,5 в останніх під дією навантаження виникають пружні деформації, які викликають перебудову структури солей. Внаслідок цього порода ущільнюється, ії міцність збільшується і деформації згасають. Міжкамерний цілик не руйнується, а переходить у новий стійкий стан. Стійкість зберігається необмежений час, однак унаслідок пластичних властивостей солей проходить вікове повільне осідання ціликів і сходження стінок камер. Термін осідання визначається декількома століттями.

На калійних і соляних рудниках, які проєктували й відпрацьовували у другій половині $\mathrm{XX}$ століття, запас міцності ціликів переважно більший 2,5. Завдяки достатньому запасу міцності на переважній площі шахтних полів деформації ціликів не досягають критичних значень. У деформуванні міжкамерних ціликів із запасом міцності від 1,4 до 2,5 (жорстко-пластичних) виділяють три стадії: початкову, активну і згасаючу.

Активна стадія деформації починається після того, як осідання досягає величини 2-3 \% від висоти ціликів. Цілики спочатку набувають бочкоподібної форми, а потім можуть обвалитися спонтанно. Роздавлені цілики заповнюють камери і після того деформації гірничого масиву поступово згасають. Масив покриваючих порід осідає, утворюється мульда зрушення. При високому рівні грунтових вод у мульді утворюється озеро.

При запасі міцності менше 1,4 міжкамерні цілики відносять до податливих, які зберігають свою несучу здатність лише на короткий термін. Деформація ціликів закінчується їх руйнуванням, при цьому руйнується і захисна стелина.

Важливий вплив на стійкість виробок мають гідрогеологічні умови. Розрізняють наступні види фізичного впливу рідини на напружений стан гірничого масиву (табл. 1). Здебільшого всі ці впливи проявляються одночасно.

Таблиия 1 - Інженерно-геологічні процеси, обумовлені впливом рідини

\begin{tabular}{|c|c|c|}
\hline \multirow{2}{*}{ Діючі сили } & \multicolumn{2}{|c|}{ Процеси, обумовлені впливом рідини } \\
\cline { 2 - 3 } & В області водонасичення & У покриваючих водоупорах \\
\hline $\begin{array}{c}\text { Гідростатичний } \\
\text { тиск }\end{array}$ & $\begin{array}{c}\text { Деформації, обумовлені зміною тиску пок- } \\
\text { риваючих порід }\end{array}$ & $\begin{array}{c}\text { Загальне піднятя (опускання) покрива- } \\
\text { ючої товщі }\end{array}$ \\
\hline $\begin{array}{c}\text { Зважуючий } \\
\text { вплив }\end{array}$ & $\begin{array}{c}\text { Деформації, обумовлені зміною густини рі- } \\
\text { дини, що насичує обводнену породу }\end{array}$ & $\begin{array}{c}\text { Підняття (чи опускання), обумовлене } \\
\text { зменшенням геостатичного тиску }\end{array}$ \\
\hline Градієнт напору & $\begin{array}{c}\text { Суфозія, зростання фільтраційного опору, } \\
\text { фільтраційний опір або кольматація та філь- } \\
\text { траційне ущільнення }\end{array}$ & $\begin{array}{c}\text { Уворення каверн, розмивання на кон- } \\
\text { такті з проникливими породами }\end{array}$ \\
\hline $\begin{array}{c}\text { Молекулярно- } \\
\text { поверхневі сили }\end{array}$ & $\begin{array}{c}\text { Розклинююча дія рідини, набухання або уса- } \\
\text { дка у результаті змін поверхневого натягу на } \\
\text { межі твердої та рідкої фаз }\end{array}$ & $\begin{array}{c}\text { Розмокання оголеної поверхні, } \\
\text { набухання або усадка, втрата стійкості } \\
\text { виробок }\end{array}$ \\
\hline
\end{tabular}

Величина осідання земної поверхні при запасі міцності менше 2,5 залежить від коефіцієнту вилучення корисної копалини і висоти виробленого простору. За даними натурних вимірів, осідання земної поверхні завжди менше за переміщення покрівлі пласта внаслідок зависання залягаючих вище порід та їхнього розрихлення. П. К. Гаркушин [12] на основі натурних спостережень пропонує визначати максимальне кінцеве осідання поверхні $\eta$ за формулою:

$$
\eta=\frac{h \times \Pi \times K_{s}}{n},
$$

де $h$ - висота камер, $\Pi$ - ступінь підроблення гірничого масиву, $K_{s}$ - коефіцієнт вилучення корисної копалини, $n$ - коефіцієнт запасу міцності ціликів.

Ступінь підроблення визначають із формул: 
TECHNICAL SCIENCES AND TECHNOLOGIES

$$
\begin{aligned}
& \Pi=(\Pi 1 \times \Pi 2) \times 0,5 ; \\
& \Pi 1=0,8 \frac{D 1}{\left(H_{c p}-0,12\right)} ; \Pi 2=0,8 \times \frac{D 2}{\left(H_{c p}-0,12\right)},
\end{aligned}
$$

де $D 1, D 2$ - розміри виробленого простору (падіння і простягання), Нср - середня глибина від земної поверхні до покрівлі камер. У випадку, якщо П1, і П2>1, їх приймають рівними одиниці.

Проведені розрахунки для рудника «Калуш» дали наступні результати [13] (розрахунок проведено без урахування твердої закладки, фактична максимальна глибина мульди 2,5 м, табл. 2):

Таблиия 2 - Оиінка глибини мульд зрушення над видобувними полями
\begin{tabular}{|c|c|}
\hline Видобувне поле & Максимальне осідання, м \\
\hline Північне сильвінітове & $5,1^{*}$ \\
\hline Північне каїнітове & 9,1 \\
\hline Центральне каїнітове & 7,1 \\
\hline Хотинське сильвінітове & 7,4 \\
\hline
\end{tabular}

На основі багатолітнього світового досвіду спеціалістами з гірничої геомеханіки соляних шахт встановлено, що, незалежно від затоплення насиченими розсолами, опорні цілики з часом руйнуються [5]. Геологічні властивості солей обумовлюють втрату ними міцності під навантаженням, при замочуванні та з часом. Довготермінова міцність зразків кам'яної солі становить приблизно 60 \% від опору стисканню при швидкому навантаженні. У зволожених зразків кам'яної солі довготермінова міцність менша приблизно удвічі, при тому швидкість деформацій збільшується у 3-4 рази.

При навантаженнях у зразках кам'яної солі проявляються деформації стабільного ковзання. Коли навантаження досягає 55 \% від опору одноосному стисканню (14-15 МПа), ковзання через 160 діб переходить у прогресуюче. Наприклад, при замочуванні зразків каїнітової породи у насиченому $\mathrm{NaCl}$ розсолі вологість досягає 1-5 \%, при тому міцність зменшується з 40 до 7,4 МПа. При замочуванні зразків сильвініту і каїніту в насиченому відносно до калійної руди розчині вологість зразків збільшилася до 4,5 \%, при тому опір стисканню зменшується у чотири рази [14]. Тому несуча здатність ціликів у соляних шахтах визначається терміном їхньої служби. Останній визначається за формулою [10]:

$$
T=0.317 * 10^{-7}\left[\frac{(n-1) *(1-\alpha)}{\delta}\right] * \frac{1}{(1-\alpha)},
$$

де $\mathrm{n}$ - коефіцієнт запасу міцності, $\alpha$ i $\delta$ - коефіцієнти, які залежать від запасу міцності:

$$
\begin{aligned}
& \alpha=0.716+\frac{0.115}{n} . \\
& \delta=\left(78+\frac{297.7}{n}\right) * 10^{-5} .
\end{aligned}
$$

Орієнтовно, при запасі міцності 2,5 термін служби ціликів становить 100 років.

Цілики шахти «Калуш» мають різний коефіцієнт міцності. Старі виробки, де ширина ціликів становить всього 4 м, мають коефіцієнт запасу менше 2,5. Ділянки з такими ціликами є дуже небезпечними. Ділянки, які відробляли в другій половині двадцятого століття, мають коефіцієнт запасу більше за 2,5 і за результатами розрахунків можуть стояти ще кілька десятиліть.

\section{Висновки.}

1. Наведений короткий огляд закономірностей деформації гірничого масиву над підземними виробками. Показано, що можливість утворення і динаміка деформацій залежать від коефіцієнту запасу міцності ціликів. При значенні коефіцієнта запасу більше 2,5 цілики збе- 
рігають стійкість десятиліттями. В інтервалі значень коефіцієнту запасу 1,4-2,5 цілики поступово руйнуються, на земній поверхні утворюються мульди зрушення. При коефіцієнті запасу менше 1,4 цілики руйнуються під час проведення гірничодобувних робіт.

2. Приплив у шахти прісної води призводить до підрізання основи ціликів і втрати їхньої стійкості, що супроводжується масовим обрушенням покриваючої товщі. Провали земної поверхні над гірничими виробками не пов'язані зі соляним карстом, а $є$ наслідком обвалення покрівлі гірничих виробок, зокрема луговень.

3. Затоплення виробок насиченим розсолом збільшує стійкість підземних виробок за рахунок Архімедових сил зважування. Однак при замочуванні солей їхня міцність зменшується, тому з часом цілики втрачають стійкість. Термін стійкості залежить від коефіцієнту запасу.

4. Глибина мульди зрушення над гірничими виробками залежить від коефіцієнту вилучення корисної копалини і від ступеня заповнення виробок сухим матеріалом. При неглибокому заляганні рівня грунтових вод у мульді зрушення утворюються озера.

5. На основі архівних даних наведена характеристика стану гірничих виробок у зонах впливу видобувних полів рудника «Калуш». Показано, що практично на всіх видобувних полях коефіцієнт запасу менший за 2,5, що обумовлює просідання земної поверхні на території всіх полів. При цьому внаслідок різноманітності параметрів ціликів і камер деформації носять нерівномірний характер - від раптових провалів до плавного просідання.

6. Для відслідковування фактичної динаміки утворення мульд осідання над шахтними полями найдієвішими є методи геодезичних спостережень, зокрема періодичне (з частотою хоча б 1 серія/рік) виконання геометричного нівелювання існуючих реперних ліній. У результаті такого моніторингу можна зафіксувати зміни швидкості осідань точок земної поверхні та встановити місця можливого утворення провалів.

7. При визначенні осідань земної поверхні методом нівелювання реперів профільних ліній потрібно вирішувати складні аналітико-статистичні завдання, такі як визначення опорного вихідного репера та виявлення помилок у відомостях спостережень минулих років.

8. Величини фактичних осідань земної поверхні в межах досліджуваних шахтних полів не виходять за межі розрахованих геолого-механічним методом значень.

\section{Список використаних джерел}

1. Марфенко С. В. Геодезические работы по наблюдению за деформациями сооружений : учеб. пособ. Москва : МГУГиК, 2004.

2. Кабалин Е. В., Лохов В. С. Принципы ведения постоянного мониторинга на геодинамических объектах. Геопрофи. 2012. № 2. С. 58-61.

3. Malinowska A. A. Fuzzy inference-based approach for building damage risk assessment on mining terrains. Engineering Structures. 2011. № 33(1). Pp. 163-170.

4. Malinowska A., Hejmanowski, R. Building damage risk assessment on mining terrains in Poland with GIS application. International Journal of Rock Mechanics and Mining Sciences. 2010. Vol. 47(2). Pp. 238-245.

5. Baryła R., Oszczak S., Paziewski J., Wielgosz, P. Analiza deformacji terenu na Obszarze Starego i Głównego Miasta Gdańska wyznaczonych za pomocą techniki GPS. Wyniki z pięciu kampanii pomiarowych, Prace Naukowe Instytutu Górnictwa Politechniki Wroctawskiej. 2009. Issue 129. Pp. 3-8.

6. Moss J. L. Using the Global Positioning System to monitor dynamic ground deformation networks on potentially active landslides. International Journal of Applied Earth Observation and Geoinformation. 2000. Vol. 2, Issue 1. Pp. 24-32.

7. Гавриленко Ю. Н. Расчет сдвижений и деформаций земной поверхности на больших площадях. Наукові праиі УкрНДМІ НАН Украӥни. 2013. № 13 (частина I). С. 271-287.

8. Гайдін А. М., Дяків В. О., Зозуля I. І. Знешкодження джерел забруднення довкілля в зоні впливу Калуського промислового району. П'ята міжнародна науково-практична конференція «Надрокористування в Украӥні». Трускавець, 2018. С. 8-16. 
TECHNICAL SCIENCES AND TECHNOLOGIES

9. Рудько Г. І., Яковлєв Г. О., Рагозін О. Л. Моніторинг процесонебезпечних територій та розрахунок ризику техноприродних аварій і катастроф. Київ : Знання, 1997. 79 с.

10. Пермяков Р. С., Романов В. С., Бельды М. П. Технология добычи солей. Москва : Недра, $1981.48 \mathrm{c}$.

11. Ещенко А. Н. Подземная добыча каменной соли на Артемовском месторождении. Донецк : Норд-Пресс, 2011. 144 с.

12. Гаркушин П. К. Расчёт параметров сдвижения земной поверхности при разработке калийных месторождений по камерно-столбовой системе. Горный журнал. 1995. № 12. С. 26-29.

13. Рабочий проект ликвидации рудника «Калуш» (Корректировка). Том. 1. Общая пояснительная записка и технико-экономическая часть. Г. Львов, 1986. Фонди ГІРХІМПРОМ, інв. № 26671.

14. Проскуряков Н. М., Пермяков Р. С., Черников А. К. Физико-механические свойства соляных пород. Ленинград : Недра, 1973. 272 с.

\section{References}

1. Marfenko, S. V. (2004). Geodezicheskie raboty po nabliudeniiu za deformatciiami sooruzhenii [Geodetic work to monitor the deformation of structures]. MGUGiK.

2. Kabalin, E. V., Lokhov B. C. (2012). Printcipy vedeniia postoiannogo monitoringa na geodinamicheskikh obektakh [Principles of continuous monitoring at geodynamic objects]. Geoprofi, (2), 58-61.

3. Malinowska, A. A. (2011). Fuzzy inference-based approach for building damage risk assessment on mining terrains. Engineering Structures, 33(1), 163-170.

4. Malinowska, A., Hejmanowski, R. (2010). Building damage risk assessment on mining terrains in Poland with GIS application. International Journal of Rock Mechanics and Mining Sciences, 47(2), 238-245.

5. Baryła, R., Oszczak, S., Paziewski, J., Wielgosz, P. (2009). Analiza deformacji terenu na Obszarze Starego i Głównego Miasta Gdańska wyznaczonych za pomocą techniki GPS. Wyniki z pięciu kampanii pomiarowych, Prace Naukowe Instytutu Górnictwa Politechniki Wroctawskiej, 129, 3-8.

6. Moss, J. L. (2000). Using the Global Positioning System to monitor dynamic ground deformation networks on potentially active landslides. International Journal of Applied Earth Observation and Geoinformation, 2(1), 24-32.

7. Gavrilenko, Iu. N. (2013). Raschet sdvizhenii i deformatcii zemnoi poverkhnosti na bolshikh ploshchadiakh [Calculation of displacements and deformations of the earth's surface over large areas]. Naukovi pratci UkrNDMI NAN Ukrä̈ni, (13(I)), 271-287.

8. Haidin, A. M., Diakiv, V. O., Zozulia, I. I. (2018). Zneshkodzhennia dzherel zabrudnennia dovkillia v zoni vplyvu Kaluskoho promyslovoho raionu [Neutralization of sources of environmental pollution in the area of influence of Kalush industrial area]. Piata mizhnarodna naukovo-praktychna konferentsiia «Nadrokorystuvannia v Ukraini» (pp. 8-16).

9. Rudko, H. I., Yakovliev, H. O., Rahozin, O. L. (1997). Monitorinh protsesonebezpechnykh terytorii ta rozrakhunok ryzyku tekhnopryrodnykh avarii i katastrof [Monitoring of process-hazardous areas and calculation of the risk of techno-natural accidents and catastrophes]. Znannia.

10. Permiakov, R. S., Romanov, V. S., Beldy, M. P. (1981). Tekhnologiia dobychi solei [Salt mining technology]. Nedra.

11. Eshchenko, A. N. (2011). Podzemnaia dobycha kamennoi soli na Artemovskom mestorozhdenii [Underground mining of rock salt at the Artyomovskoye deposit]. Nord-Pres.

12. Garkushin, P. K. (1995). Raschet parametrov sdvizheniia zemnoi poverkhnosti pri razrabotke kaliinykh mestorozhdenii po kamerno-stolbovoi sisteme [Calculation of the parameters of the earth's surface displacement during the development of potash deposits according to the chamber-pillar system]. Gornyi zhurnal, (12), 26-29.

13. Rabochii proekt likvidatcii rudnika «Kalush» (Korrektirovka) [Detailed design for the liquidation of the Kalush mine (Adjustment)]. Vol. 1. Obshchaia poiasnitelnaia zapiska i tekhnikoekonomicheskaia chast [General explanatory note and technical and economic part]. (1986). Fondi GIRKhIMPROM, № 26671.

14. Proskuriakov, N. M., Permiakov, R. S., Chernikov, A. K. (1973). Fiziko-mekhanicheskie svoistva solianykh porod [Physical and mechanical properties of salt rocks.]. Nedra. 
UDC 528.422

\section{Oksana Gera, Mykola Hrynishak, Lyubov Dorosh \\ FACTORS OF THE SUBSIDENCE TROUGH FORMATION OVER THE UNDERGROUND MINE WORKINGS}

The mine method of potassium salts deposits developing is usually accompanied by the formation of great underground cavities, which causes gradual or sudden subsidence of the earth's surface over the minefields. These processes can cause significant damage to both land resources (formation of siltation and even salt lakes because of subsidence of the earth's surface) and buildings located in the zone of influence of the subsidence trough. Chasms are especially dangerous, as they pose a direct threat to the lives and health of people habituated in the insecure areas.

Analysis of the factors of the landslides formation over the mine workings confirmed that the subsidence of the earth's surface is a consequence of the collapse of the mine workings roof, and is not directly related to the salt karst. While flooding workings with saturated brine, the stability of underground workings increases due to the Archimedes' weighing forces, and the stability period depends on the safety factor.

The dependence of the depth of the trough over the mine workings on the coefficient of mineral extraction and on the degree of the workings filling with dry material was revealed. The lake formation in the trough shifts occurs in case of shallow groundwater level.

The article presents the results of geological and surveying investigation of the minefields of the Kalush mine (KalushGolynsk salt deposit). The results of calculations of the maximum depth of the subsidence trough depending both, on the safety factor of the pillars and the inflow of liquid into the mine, are presented. The analysis of influence of mines filling with saturated salt brines on destruction of pillars is conducted. Based on the archival data, the condition characteristic of extractive fields of the mine "Kalush" is described. It appeared that in almost all mining fields the safety factor is less than 2.5, which causes earth's surface subsidence above all the fields.

The values of the actual subsidence of the earth's surface of the mine fields of the Kalush mine, determined by the method of high-precision geometric leveling, currently do not exceed the maximum values obtained on the basis of geological and mechanical calculations.

Keywords: deformation of the earth's surface; mine workings; estimation of a shift trough depth.

Fig.: 1. Tables: 2. References: 14.

Гера Оксана Василівна - кандидат технічних наук, доцент кафедри геодезії та землеустрою, Івано-Франківський національний технічний університет нафти і газу (вул. Карпатська, 15, м. Івано-Франківськ, 76019, Україна).

Gera Oksana - PhD in Technical sciences, Associate Professor at the Department of Geodesy and Land Management, Ivano-Frankivsk National Technical University of Oil and Gas (15 Karpatska Str., 76019 Ivano-Frankivsk, Ukraine).

E-mail: geraoksana@gmail.com

ORCID: https://orcid.org/0000-0001-6670-2820

Researcher ID: K-2209-2017

Гринішак Микола Ярославович - асистент кафедри геодезії та землеустрою, Івано-Франківський національний технічний університет нафти і газу (вул. Карпатська, 15, м. Івано-Франківськ, 76019, Україна).

Hrynishak Mykola - Assistant at the Department of Geodesy and Land Management, Ivano-Frankivsk National Technical University of Oil and Gas (15 Karpatska Str., 76019 Ivano-Frankivsk, Ukraine).

E-mail: nikolaygrynishak@gmail.com

ORCID: https://orcid.org/0000-0002-0422-8681

Дорош Любов Ігорівна - інженер кафедри геодезії та землеустрою, Івано-Франківський національний технічний університет нафти і газу (вул. Карпатська, 15, м. Івано-Франківськ, 76019, Україна).

Dorosh Lyubov - Engineer at the Department of Geodesy and Land Management, Ivano-Frankivsk National Technical University of Oil and Gas (15 Karpatska Str., 76019 Ivano-Frankivsk, Ukraine).

E-mail: liubov.dorosh@gmail.com

ORCID: https://orcid.org/0000-0003-2971-4034

Гера О., Гринішак М., Дорош Л. Чинники утворення мульд осідання земної поверхні у районах підземних гірничих виробок. Технічні науки та технологіï. 2021. № 2(24). С. 227-234. 